\title{
Academic Ableism: Disability and Higher Education (Corporealities: Discourses of Disability)
}

\author{
Jay Timothy Dolmage \\ Ann Arbor, MI. University of Michigan. 244 \\ pages. $\$ 70.19$ (hardcover). 24.95 \\ (paperback). 14.72 (Kindle). \\ Reviewed by Ayesha Alnajar, Ahmed Alfalah \\ Saint Louis University
}

DOI: $10.7176 / \mathrm{JEP} / 12-3-06$

Publication date: January $31^{\text {st }} 2021$

In Academic Ableism: Disability and Higher Education (Corporealities: Discourses Of Disability), Dolmage represented an influentially pioneer work in the field of special education, particularly in the field of Disability and Higher Education; not only are the materials presented in subsequently logical and organized style, but also one of the most impressive characteristics of the book is the supreme readability and comprehensibility, which makes it one of the must-read texts for those in relation to this field of study. Consequently, Dolmage's work is very likely to be of interest to a variety of scholars in numerous interdisciplinary fields, such as learning disabilities, speech and hearing science, assistive technology, and more. By no means should this not be surprising; Jay Timothy Dolmage is associate professor of English at the University of Waterloo and received his doctoral degree from Miami University of Ohio. Since then, he has published a number of books related to learning and disability, for which he received a considerable number of awards, such as the Theresa J. Enos Award for the best essay in the journal Rhetoric Review, which was "Breathe Upon Us as Even Flame: Hephaestus, History and the Body of Rhetoric.”, written in the Rhetoric Review journal, by 25.2 ((Spring 2006, pp. 119-140).

In the introduction, Dolmage clearly declares that he is addresses the rhetoric of disability connected to learning issues and the social scope of disability in terms of its relationships to education, with focus on higher education and how it was framed and gradually altered. He points out, "for most of the $20^{\text {th }}$ century, people with disabilities were institutionalized in asylums, 'schools' for the 'feeble minded' and other exclusionary institutions, locations that became the dark shadows of the college and university ... what is ironic about this is that if you flip a few key points, you have great description of the universities also being developed in the same period".

The book is comprised of five chapters, sorted into an introduction followed by five major parts, each of which addresses ad hoc key point of the topic. In Chapter 1, "Steep Steps", the book sheds lights of the historical aspects of the concept of disability among society and academia of institutions, with more focus on the suppositions regarded to disability that were found and raised in university societies, i. e., campuses, about who is qualified to be enrolled.

In Chapter 2, titled in: "The Retrofit," the author attempts to dismantle contemporary rhetoric about the accommodations set to address and fix the relationship and conceptualization of disability in society and academia and how such an attempt can clearly reveal the persistence of unwanted discriminations. The author reviews a number of rhetorical examples of addressing disability, such as "Cover Your Ass", and "The Effect of Accommodation" moving through describing the transfer from education to negotiation.

In the beginning of Chapter 3, "Imaginary College Students" (the shortest chapter of the book), Dolmage continues "Imaginary College Students", Dolmage maintains addressing and discussing the previous issue, thus defining the rhetorical aspects of addressing students based on being "able-minded" or "able-bodied". Appeals for support were mistakenly viewed and treated based on the student's "legitimacy" of having the right to receive support based on his/her mind or body's ability. This can imply that, in contrary, supports for students with disabilities were viewed negatively as a lower degree or right to support compared to support given to able-minded and able-bodied students.

Chapter 4, the longest chapter and the peak of the book's ideas, is titled "Universal Design". The concept of Universal Design refers to what is seen as the panacea that can aid students with disabilities when being enrolled in higher education. However, Dolmage asserts the problem is still standing and the historical gaps are still observable in higher educational institutions due to making the priority in addressing Universal Design to the institutional interests. This chapter appears to be the pioneer chapter as it helps readers and researchers develop a reliable view to the ongoing scene. Criticizing the usability of Universal Design in the contemporary context is primarily related to the interest convergence, based on which academic institutions define Universal Design.

The last chapter in the book, chapter 5, titled in "Disability on Campus, On Film: Framing the Failures of Higher Education", attempts to philosophize that the rhetoric of 'disability' concept in higher education is vastly and mostly borrowed from the reproduction of the issue in media. This tendency of treating the rhetorical construction of disability in higher education based on media reproduction is a major explanation of why academia 
institutions suffer failure in accommodating students with disabilities.

The book's price is reasonable compared to the prices of academic affairs-related publications in general, especially with the considerable eminent gains of the book. As the author of this book review, doctoral student, and special education teacher, I find this statement to be true; the book is concise, informative, comprehensive balanced, and affordable. Not only may the book's content be used in learning disabilities and higher education applications and approaches, it also can be helpful in building firm understanding in a considerable number of theoretical and practical bases, especially in certain related fields, such as learning disabilities.

The author's purpose for writing this book is explained clearly in the introduction, in which he indicates that he attempts to describe the problems of rhetoric construction of the term "disability" in the academic institutions and the ongoing and continuous negative views and procedures with accommodating students with disabilities in the college setting. Academic ableism as it relates to "able bodies" and "non-able bodies" is described as "a genre or category of statements and sentiments that distance the speaker from responsibility for the selective, stratifying forces within higher education, selecting and stratifying functions that depend upon ableism and disablism to make sure that privilege is portioned out only along traditional lines: to ensure that students who move, think, or express themselves outside of a narrow set of norms will not thrive or survive in college" (p.35). Dolmage's message is to rethink the rights of students with disabilities in being accommodated in higher education and academic institutions as they do not seem to be soundly addressed and treated even in the contemporary rhetoric, which has not historically changed much according to tracing the historical stages of the rhetoric construction of disability, society and academia by the author.

From the viewpoint of this reviewer, a researcher in the field of special education, Academic Ableism: Disability and Higher Education is an outstanding academic publication that addresses certain roots of describing the problem of disability and academia. Such an academic contribution to the field of special education and higher education can play an important role in raising individual, social and institutional awareness of the concept of disability in the higher education setting. It can be considered one of the most recent attempts to trace the issue of disability and higher education returning to the historical roots. One of the strengths of the book is its argument that, historically, little has occurred to affect the relationship between disability and higher education, implying that social justice is still responsible for the inequality of this relationship compared to the relationship between academia and students without disabilities.

Academic Ableism: Disability and Higher Education is a meaningful contribution that is received with admiration among scholars and researchers in the field of special education and special education and higher education. It comprehensively sheds lights on dimensional roots of disability, such as society and media, to describe the ongoing rhetoric and argue the changes that occurred affecting the status of social justice and disability. Finally, this book calls for academic institutions and civic institutions to consider academic ableism in the scope of culturally changing views and procedures of addressing disability in terms of social justice and academic ableism.

\section{References}

Linton, S. (1998) Claiming Disability. New York, NY: New York City Press. 